\title{
ICT Needs for Rural India - A Review
}

\section{Radhika Rajesh Sharma, Aleena Vakeel Ahemad Sheikh}

CSE, Jawaharlal Darda Institute of Engineering and Technology, Yavatmal , Maharashtra , India

Article Info

Volume 8, Issue 6

Page Number : 492-496

\section{Publication Issue}

November-December-2021

\section{Article History}

Accepted : 15 Dec 2021

Published : 30 Dec 2021

\section{ABSTRACT}

India is a developing country and for its growth and advancement it is important to bring positive changes and implement new techniques .In this highly populated country ,it's crucial to tackle with the major issues like chronic unemployment ,high level of illiteracy, women empowerment, lack of medical facilities, etc. Strengthening and boosting rural livelihood plays a main role into development. The paper is focusing on promoting the rural economy and improving quality of life in remote places. ICT i.e. information and communication technology is powerful media for overcoming these challenges. ICT focuses on improving agriculture activities and enforcing communication and information technologies, helps people in rural area to grow and to create more sources of income. And decrease the poverty rate of the country. And this includes promoting sustainable agriculture, empowering women, introduce new techniques and equitable access to land, water, financial resources, education to all, strengthen health-care facilities, arrange training and awareness programs, expand access to market, promote gender equality and many more. ICT is helping and changing livelihoods of many and if this continues so there will be no gap between rural area and urban area.

Keywords: Strengthening And Boosting, Advancement , Crucial , Awareness.

\section{INTRODUCTION}

India is a country where the primary occupation of the people is agriculture. But in these 10-20 years it is observed that the conditions like natural or climatic disasters make the farmers helpless to carry on agriculture and to sustain life. There are various aspects in which it is possible to study on this topic. The role of Information Technology to develop agricultural research, education and extension to improve quality of life in rural area is well established.
IT can help an average Indian farmer to get relevant information regarding agro inputs, crop prodcuction technologies, agro processing, market support, agrofinance and management of farm agribusiness [1].

\section{"Information Communication Technology" concentrates on these three words: Information, Communication and Technology; to promote information via communication with the help of technology. Communication should be a process that}


contains the forces of backlash and promotes the forces of transformation and survival.[2]

The subject is quite vast and there are many aspects on which effective work can be done. Roughly, it can be seen as:

- Rural development

- Ways to implement using ICT

- Problems faced during implementation of ICT solutions.

Rural development can contribute a lot in progress of any nation. Information that would otherwise be conveyed through face-to-face contact, post, courier, print delivery, telegraph or telephone may instead be communicated in digital electronic form via the Internet.[3]

The following four points shortly give the description of points described in the paper :.Rural Development: The rural development is an overall development in terms of socio-economic and cultural development anytime, anywhere feature of ICTs is the ability to transcend time and space.[4]

Agriculture: Also in agricultural field, the farmers are given proper guidance about the use of fertilizers, the amount in which the fertilizer should be added, etc. to the nature of the soil, for which crop the soil is more beneficial. The technology is too beneficial in the increment of yield of crops due to which farmers will be in profit. Developers are increasingly making use of new technology trends (Bughin et al. 2011) to develop and deliver such $\mathrm{m}$-services, complementing existing mobile technologies such as SMS and voice calls [5]. Latest change: "KISAN TV" channel introduction.

As a primary occupation, agriculture and agricultural based business and industries can be developed and expanded to contribute to the GDP. Many
Smartphone apps are being developed to give climate and weather updates. However, the actual situation is very contradictory. To deal with this situation, the first thing which is very important is courage, to possess a positive attitude to approach to solve the problems and find the solution for it to improve the appearance.

The rural population is at an inherent disadvantage in India as they lack the pre-requisites to participating in their country's economic growth in the tertiary, modern services sector [6]

Women empowerment: Empowering rural women is considered absolutely fundamental to increasing nutrition sensitivity in agriculture as women make up a large percentage of the agricultural labor force in developing countries. Beside this the resources and income flows that women control have been shown to have disproportionately positive impacts on nutrition security.

Women are a very dynamic personality of the society. Gender inequality is not a big issue in the today's 21st century. There are also opportunities to train some of these rural women for self employment in the IT sector [7]. The handicraft art is preserved by the Indian women, especially the Indian rural women. Four features that have characterized India since Independence continue to characterize India's elementary education system: incomplete enrolment, inequalities, poor quality, and ineffective school performance [8]. We just need to motivate them. Technology-based social empowerment especially for rural women is a new emerging concern in the present information world [9] .The difficulty she faces right from her childhood is unsafe feeling and lack of motivation. Good quality education is also the ultimate intervention in terms of promoting empowerment: it endows individuals with capabilities and a sense of their rights ."Mahila Bachatgat" is a very good example for women empowerment. They 
have much power that they can contribute to the Indian economy and can be self-dependent.[10]

Health Care Facility: Rural individuals in India in general and tribal individuals in particular have their own beliefs and viewpoints in terms of health. The tribal communities are found throughout the country in hilly and mountainous regions. They are primarily dependent upon the natural environmental conditions, in order to fulfil their daily needs and requirements. When they experience various forms of health problems and illnesses, then too, they are dependent upon the forests and natural environments to obtain herbs and medicinal plants. The various health practices that are adopted by rural individuals include, Ayurveda, unani, siddha and naturopathy to maintain positive health care and to prevent illnesses and diseases. The occurrence of socio-economic, cultural and political assaults, arising moderately from the exploitation of human and material resources have endangered the naturally healthy environment.[11]

Education; is the only media through which we can implement the progress of rural areas. Also in the $21^{\text {st }}$ century, computer literacy or also we can say technology literacy is more important. It is important to explain the people benefits of technology and also it is also important to explain the crimes committed in the technology. The changing scenarios have been demanding professionals at various levels to adapt new ways of education and training to update their skills and knowledge for making their identity in this competitive world [12]. The nation can progress if the people are educated, especially in the rural areas because large population lives in these areas and in these areas there is scope for the development and large firms can be developed in these regions. Rural India is largely illiterate with the literacy rate 49.4 percent compared to the urban populace, where the literacy rate is 70 percent [13].

\section{Rural Development and ICT:}

Indian industry has undergone through many revolutions. The success story of the Indian IT industry has benefited only urban India [14]. The rural India was deprived from this benefit. Although the primary resource for industry is from agriculture. In developing countries like India the concept of development linked up with the rural development [15]. Also, the roads for transportations are not proper constructed. The government has taken the initiative to connect the India via roads. It can facilitate speedy, transparent, accountable, efficient and effective interaction between the public, citizens, business and other agencies [16]. It was the situation when we want to send a letter or message, many days were required. Today, e-mail facility, social media have made it possible to cover a large distance in very small time. ICT as an enabler has broken all bounds of cost, distance and time [17]. In rural areas, one cyber cafe is sufficient to make the rural citizens known to ICT. The ICT kiosk movement has been able to create a stir in local communities in terms of knowledge and know-how about the use of technology for accessing information and using it as a means to a better livelihood [18]. The world is connected under one term globalization. So, rural areas must be provided training to make good entrepreneurs. The natural resources are available in plentiful quantity. The current era of globalization, marketization and increasing competitiveness requires that every citizen should be resourceful to run their livelihood enterprises [19]. ICT is the fastest medium for communication. From the perspective of information technology, India is most widely known for its impact on global markets in the software and services sectors [20]. We can give opportunity to Indian rural markets to trade in foreign countries. ICT is a major tool to leverage the scheme for ensuring access to the target group of beneficiaries [21]. The Information and Communication Technologies have facilitated the design of solutions to deliver government services for social development at the door step of villagers [22]. 
While there is a strong link between access to ICT and development, it is not a panacea, but rather a powerful tool to tackle development challenges [23]. A strong communication channel can be established with the help of mobile phones. Rural citizens can use the toll free numbers to call and leave messages about any issue concerning their community and listen/ learn from messages left by others from the same community [24].

\section{CONCLUSION}

Following conclusions can be drawn from above description.

1) Rural development is essential to contribute the nation's progress. This is the very important thing which we need to understand. The strength of laws will work definitely to achieve this. This will reduce the standard gap between rural and urban areas.

2) The first and foremost thing to implement is education. The rural schools need to undergo a long development process. The talent is available on large scale in rural arease students. The only thing is they need facilities.

3) The mutual understanding between rural and urban areas is essentially to be exclusive. The existing gap between them is due to the standard of living, education, employment and the most important the facilities in urban areas. The both areas play the vital role in contributing nations ${ }^{\text {ee }}$ progress.

4) Use of internet can cover this gap. This gap can be eliminated by online education, expert guidance how to improve the standard of living, etc. The youths migrate from rural to urban for education and employment purposes; but they are then not interested to go back again to rural areas. The major reason behind this is their approach changes, also their standard improves too.

5) Internet is a valuable source of knowledge. ICT kiosks can be implemented for health and education, occupations, business, etc. the government is also active in making rural areas developing. Just the thing we need is to broaden our scope of thinking.

The heading of the References section must not be numbered. All reference items must be in $8 \mathrm{pt}$ font. Please use Regular and Italic styles to distinguish different fields as shown in the References section. Number the reference items consecutively in square brackets (e.g. [1]).

\section{REFERENCES}

[1]. Narendrasinh B. Chauhan, "Information Technology for Agricultural Development in India", 1- 24

[2]. Vikram Gopinath, "Role of Information and Communication Technology in the Rural Development: Study of Thangachimadam Village Resource Center and its Village Knowledge Centers," MCmS Dissertation 2007,6-35.

[3]. Nirvikar Singh, "Information Technology and Rural Development in India", University of California, Santa Cruz, USA, March 2004

[4]. Niraj Kumar Roy, "ICT-Enabled Rural Education in India", International Journal of Information and Education Technology, Vol. 2, No. 5, 527-529, October 2012

[5]. Heike Baumüller, "Facilitating agricultural technology adoption among the poor: The role of service delivery through mobile phones", Bonn, May 2012, ISSN 1864-6638,

[6]. Jasmine M. Bartolome, "How has India 's Rapidly Growing ICT Sector Impacted its Rural Poor?", Portland State University PDXScholar University Honors Theses, 2014, 5-27

[7]. Rashid Sulaiman V, N. J.Kalaivani, Nimisha Mittal, P. Ramasundaram, "ICTs and Empowerment of Indian Rural Women What can we learn from on-going initiatives", CRISP Working Paper March 2011, 11-84 
[8]. Shrabastee Banerjee, Kalyan Sankar Mandal, Priyadarshini De, "A Study on the Permeation and Scope of ICT Intervention at the Indian Rural Primary School Level”, 1-8

[9]. Dr. M. Arivanandan, "Socio-Economic Empowerment of Rural Women through ICTs", International Journal of Rural Studies, vol. 20 no. 2 Oct 2013, 2-7

[10]. Andrew Shepherd, Lucy Scott, Chiara Mariotti, Flora Kessy, Raghav Gaiha, Lucia da Corta, Katharina Hanifnia, Nidhi Kaicker, Amanda Lenhardt, Charles Lwanga-Ntale, Binayak Sen, Bandita Sijapati, Tim Strawson, Ganesh Thapa, Helen Underhill, Leni Wild, "Chronic Poverty Advisory Network Getting to zero", Overseas Development Institute 2014, 42-176

[11]. Patil, A.V., Somasundaram, K.V., \& Goyal, R.C. (2002). Current Health Scenario in Rural

[12]. www.delaval.com

[13]. Kwadwo Asenso-Okyere, Daniel Ayalew Mekonnen, "The Importance of ICTs in the Provision of Information for Improving Agricultural Productivity and Rural Incomes in Africa”, WP 2012-015: January 2012, 13-30

[14]. Ashok Jhunjhunwala, Sudhalakshmi Narasimhan, Anuradha Ramachandran, "Case Study: India”, International Telecommunication Union and Korea Agency For Digital Opportunity And Promotion", September 2004, 38-61

[15]. Arathi Chitla, "Impact of Information and Communication Technology on Rural India", IOSR Journal of Computer Engineering, Volume 3, Issue 2, July-Aug. 2012, 33-35

[16]. Anita Kelles-Viitanen, "The Role of ICT in Governing Rural Development", November 2005, 2-8

[17]. S. Rajamohan, T. Dhanabalan, "RURAL DEVELOPMENT THROUGH ICT: OPPORTUNITIES AND CHALLENGES", Volume 2, Number 2, April-Junee 2013, 354358
[18]. Arvindd Narayanan and Gaurav Chakraverty, "Running ICT Telecenters in Rural India", IFIP WG 9.4 Volume 19, No. 1, February 2009, 2131

[19]. Puneet Kumar, Dharminder Kumar, Narendra Kumar, "ICT in Local Self Governance: A Study of Rural India", International Journal of Computer Applications Volume 83 - No 6, December 2013, 32-36

[20]. J. Bussell, "Electoral Competition and Digital Development in India and South Africa", October 17, 2007, 236-240

[21]. S. Meenakshi, Dr. A. Murugan, "Enhancing Rural Development in Tamilnadu through ICT: An Evaluation of Latest Technologies in the scheme MGNREGS", International Journal of Computer Trends and Technology (IJCTT) volume 7 number 2- Jan 2014, 122-127

[22]. R.K.Gera, Yunus Parvej, Dr H.M.Rai, "Improving the Image of Rural India through E-Governance of Panchayats", International Journal of Latest Research in Science and Technology ISSN (Online):2278-5299 Vol.1,Issue 1 :30-35 ,May-June(2012), 34-35

[23]. WBCSD, "Information and communication technology" August 2012, 2-13

[24]. S M Sehgal Foundation, "5 th Annual Conference on Good Rural Governance and Citizen Participation", March 13, 2015, 3-5

\section{Cite this article as :}

Radhika Rajesh Sharma, Aleena Vakeel Ahemad Sheikh, "ICT Needs for Rural India - A Review", International Journal of Scientific Research in Science and Technology (IJSRST), Online ISSN : 2395-602X, Print ISSN : 2395-6011, Volume 8 Issue 6, pp. 492-496, November-December 2021. Available at doi $\quad$ : https://doi.org/10.32628/IJSRST218678 Journal URL : https://ijsrst.com/IJSRST218678 